\author{
東京慈恵会医科大学第 1 外科1) \\ 神奈川県衛生看護専門学校付属病院外科2) \\ 神奈川県立厚木病院外科 ${ }^{3}$ \\ 藤川亨”片山隆市”穴沢貞夫 ${ }^{11}$ \\ 岡 部 紀 正 $^{2}$ 斎 藤 玻瑠夫 ${ }^{3)}$ 桜 井 健 司 $^{11}$
}

1962年から1991年まで当科および関連病院が释検した完全直腸脱18例の手術症例に ついて，再発率と症状の改善度より各術式の有効性を検討した。症状として排便時直腸 脱出が全例に認められたか，その他便通異常を伴 5ものが18例中11例に認められた。 た括約筋不全を伴 うすのは13例あった，若年者には主として開腹直腸剝離举上仙骨前固 定術を, 高齢者でリスクの高い者には Thiersch 法もしくはGant-三輪法を施行した. 18 例中 5 例に 8 回の再発が認められ, 合計26回の手術を施行した.「Thiersch 法」10回の施 行に対して 5 回の再発,「Gant-三輪法+Thiersch 法」併用 4 回の施行に対して 2 回の再 発, 開腹直腸剝離挙上仙骨前固定術 8 回の施行に対して 1 回の再発があった，開腹直腸 剩離挙上仙骨固定術は再発に関して，おおされね良好な成績をあげたが，いずれの術式む 術前にあった便通異常を改善するまでには至らなかった。

象引用語：直腸脱，便通異常，Thiersch 法，Gant-三輪法，開腹直腸剔離举上仙骨前固定術

\section{緒眻}

直腸脱の手術には画一的に有効な方法はなく，その ため様々の術式が行われている，われわれは，1962年 から1991年までの過去30年間に経鈳した直腸脱手術应 例の手術術について, 再発率と症状の改善度からそ の有効性を検討したので報告する。

検討対象およひ方法

1962年から1991年までに当科および関連病院が経験 した完全直腸脱手術症例は18例であった。この18例に おける再発率と症状の改善度より，施行した各手術術 式の有効性を検討した。

\section{結 果}

\section{1）性年数分分布}

性別は男性 6 例，女12例で，男女比は $1 ： 2$ と，女 性に多い㑯向がみられた。手術時年齢は，20歳代 3 例， 50 墄代 4 例，60歳代 3 例，70歳代 4 例，80歳代 4 例で あった(表 1)．20歳代以下と50感代以上の 2 つのビー クがあった。 また幼少児期よりの発症が 5 例あった。

1992年12月 2 日受付 1993年 6 月14日採用
表 1 性およひ年龄分布

\begin{tabular}{c|c|c|c}
\hline 年龄 (藏) & 男性 & 女性 & 計 \\
\hline $20 \sim 29$ & 1 & 2 & 3 \\
$30 \sim 39$ & 0 & 0 & 0 \\
$40 \sim 49$ & 0 & 0 & 0 \\
$50 \sim 59$ & 4 & 0 & 4 \\
$60 \sim 69$ & 1 & 2 & 3 \\
$70 \sim 79$ & 0 & 4 & 4 \\
$80 \sim 89$ & 0 & 4 & 4 \\
\hline 計 & 6 & 12 & 18 \\
\hline
\end{tabular}

\section{2) 病絁期間}

発病から手術までの病悩期間は 1 カ月 54 年で, 平 均 11.0 年であった（表 2 ）。そのらち，男性は27.7年, 女性は2.7年であり,男性の多くは幼少時から発症して いたのに対して，女性の多くは中年以降の発症であっ た。

\section{3) 病型分類}

直腸脱の程度別分類は，Tuttleの分類を用い， I 一III度に分けた（図 1)．Tuttle I 度は，肛門縁皮局か ら肛門管部まで反転してくるもので，肛門周囲と脱出 
表 2 病迤期成

\begin{tabular}{c|c|c}
\hline 病憎期間 (年) & 男性 (例) & 女性 (例) \\
\hline $0 \sim 3$ & 2 & 11 \\
\hline $4 \sim 10$ & 0 & 1 \\
\hline $11 \sim 54$ & 4 & 0 \\
\hline 平均病悦期間 & 27.7 年 & 2.7 年 \\
\hline
\end{tabular}
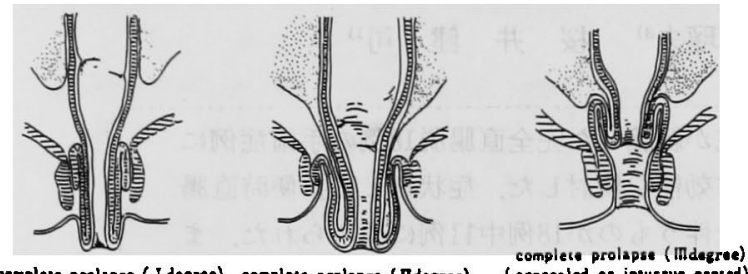

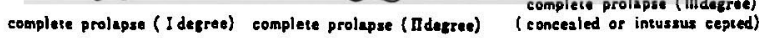

目 1 Tuttle の分類 ${ }^{20)}$

表 3 Tuttle 分䅡 ${ }^{201}$ によろ症例分布

\begin{tabular}{c|c|c|c}
\hline 年齡(歳) & I 度 & II 度 & 計 \\
\hline $20 \sim 29$ & 1 & 2 & 3 \\
$30 \sim 39$ & 0 & 0 & 0 \\
$40 \sim 49$ & 0 & 0 & 0 \\
$50 \sim 59$ & 2 & 2 & 4 \\
$60 \sim 69$ & 0 & 3 & 3 \\
$70 \sim 79$ & 0 & 4 & 4 \\
$80 \sim 89$ & 0 & 4 & 4 \\
\hline 計 & 3 & 15 & 18 \\
\hline
\end{tabular}

部との間に深い清を生じない．Tuttle II 度では，肛門 管は正常の位固にあり，直腸だけが反転してくるるの で，肛門縁の皮席と脱出直腸反転部との間に，深い溝 ができる. Tuttle III 度は, 直腸膨大部内での直腸重皘 をいら。

18例の各型頻度は（表 3）の如くである. I 度～II 度が大半を占め林度は認めなかった，また，高龄者は II度が多い傾向にあった。

\section{4) 缡床症状}

症状は，排便時直腸脱出が全例に認められたが，そ の他便秘, 粘液便, 排便時出血, 排便困難等を伴うす のが18例中11例（61.1\%）に認められた。ま，括約 筋不全を伴 5 むのが18例中 13 例 $(72.2 \%)$ に認められ た（表 4).

\section{5) 手術術式}

18 例中 5 例に再発が認められ, 合計26回の手術が行
衰 4 亩渴脱の症状（脱出以外の症状）

\begin{tabular}{ll}
\hline 便秘 & 9 例 \\
排便困難 & 3 例 \\
粘液便による下着污染 & 1 例 \\
排便時出血 & 1 例 \\
\hline
\end{tabular}

重複例あり

表 5 再発と手術回数

\begin{tabular}{c|c|c|c|c|c}
\hline \multirow{2}{*}{} & \multirow{2}{*}{ 症例数 } & \multicolumn{4}{|c}{ 手術回数 } \\
\cline { 3 - 6 } & & 1 回 & 2 回 & 3 回 & 4 回 \\
\hline 非再発 & 13 & 13 & & & \\
\hline 再発 & 5 & & 3 & 1 & 1 \\
\hline 計 & 18 & 13 & 3 & 1 & 1 \\
\hline
\end{tabular}

表 6 手術術式と再発

\begin{tabular}{|c|c|c|}
\hline 可 牙術回数 $\cdot$ 再発 & 手術回数 & 再発回数 \\
\hline Thiersch 法 & 10 & 5 \\
\hline Gant-三棆法 + Thiersch 法 & 4 & 2 \\
\hline Gant-三法法+Thiersch 变法 & 4 & 0 \\
\hline 直渴到崔挙上仙骨前固定術 & 4 & 1 \\
\hline 直腸制離誉上仙角前固定術 $+\mathrm{s}$ 状結晹切除 & 4 & 0 \\
\hline 計 & 26 & 8 \\
\hline
\end{tabular}

われた。手術回数別には，手術 1 回は13例，手術 2 回 は 3 例，手術 3 回は 1 例，手術 4 回は 1 例であった(表 5). 高龄者に対してはリスクを考え経肛門術式を，若 年者に対しては経腹術式を施行した。

26回の手術の5ち,「Thiersch 法」は10回,「Gant-三 輪法拉よび Thiersch 法併用」4回，「Gant-三輪法およ びThiersch 变法併用」4回が施行された。 われわれ は, 肛門輪縫縮術で銀線の代わりに合成の材料テトロ ンのリボンを用いた手術をThiersch 変法としてい ろ。また，8例に対しては，直腸を腹膜より全周剥離 挙上し直腸後壁と仙骨前靶帯, 直腸左壁と腸腰筋穊膜 を縫合固定しダグラス窩を程合閉鎖する，開腹直腸 利離举上仙骨前回定術（以下直腸固定術と略す）を施 行した。 また同手術では, S 状結腸過長症があった 4 例 に対して S 状結腸切除術が併せて施行された。

6) 術式と再発

手術術式と再発の関保をみると（表 6)，「Thiersch 法」10回に対して 5 回,「Gant-三輪法+Thiersch 法」 併用 4 回に対しては 2 回再発した.「Gant-三輪法十 
表 7 再発例の術式

\begin{tabular}{|c|c|c|c|c|}
\hline 症例 & 年龄 & 性別 & Tuttle 分類 & 再発例の術式 \\
\hline 1 & 71 & 女 & II & Thiersch 法 $\rightarrow$ 再発 $\rightarrow$ Thiersch 法 \\
\hline 2 & 82 & 女 & II & $\begin{array}{c}\text { Thiersch 法 } \rightarrow \text { 再発 } \rightarrow \text { Thiersch 法 } \rightarrow \text { 再発 } \rightarrow \\
\text { Thiersch 法 }\end{array}$ \\
\hline 3 & 70 & 女 & II & Thiersch 法 $\rightarrow$ 再発 $\rightarrow$ Thiersch 法 + Gant 三輸法 \\
\hline 4 & 70 & 女 & II & $\begin{aligned} \text { Thiersch 法 } \rightarrow & \rightarrow \text { 再発 } \rightarrow \text { Thiersch 法 + Gant 三渝法 } \rightarrow \\
& \text { 再発 } \rightarrow \text { Thiersch 法 + Gant 三渝法 } \rightarrow \\
& \text { 再発 } \rightarrow \text { Thiersch 法 }\end{aligned}$ \\
\hline 5 & 26 & 男 & II & 直腸仙骨固定術 $\rightarrow$ 再発 $\rightarrow$ Thiersch 変法+Gant 三輸法 \\
\hline
\end{tabular}

表 8 術啳の排便状況・愁訴・合併症と衍式

\begin{tabular}{|c|c|c|c|c|}
\hline \multirow[b]{2}{*}{ 排便状況 } & \multirow[b]{2}{*}{$\begin{array}{l}\text { 郝前と変わらす } \\
\text { 便秘增强 }\end{array}$} & \multicolumn{2}{|c|}{ 経腹術式 } & 怪肛門術式 \\
\hline & & $\begin{array}{l}5 \text { 例 } \\
3 \text { 例 }\end{array}$ & $\begin{array}{l}5 / 8(63 \%) \\
3 / 8(38 \%)\end{array}$ & $\begin{array}{c}10 \text { 例 } 10 / 10(100 \%) \\
0\end{array}$ \\
\hline 得部慗新 & 排便時腹痛 & 1 例 & $1 / 8(13 \%)$ & 0 \\
\hline 合併症 & Subileus & 1 例 & $1 / 8(13 \%)$ & 0 \\
\hline
\end{tabular}

Thiersch 変法」併用 4 回では再発はなかった。「直腸固 定術」4 回に対しては 1 回の再発があった。「直腸固定 術 $+S$ 状結腸切除術」4 回では再発はなかった。表 7 に 再発例の経過を示すが， 5 例中 4 例は70歳以上の高龄 者で初回手術が経肛門手術を，1例は若年者で経腹手 術を施行した，5例のうち 1 例は，「Gant-三輪十 Thiersch 变法」併用を施行した．その後追跡調查しえ た限りでは再発はなかった。 4 例は，再度「Thiersch 法」むしくは「Thiersch 法+Gant-三輪法」併用を施 行し，そのらち 2 例に再発をみている。程腹手術を施 行した 8 例中 1 例に再発があった。この症例は，術前 より肛門括約筋不全があり，㭪後 6 力月目に再発した ため，「Gant-三輪法＋Thiersch 变法」併用を施行し た，その後，現在まで再発をみていない，直腸固定術 は，再発率からは最む良好な成績であった。

\section{7) 術式と排便状況およU合併症}

つぎに術後の排便状況に関して，経肛門術式と経腹 術式に分け検討した（表 8)。释肛門術式では, 術前, 㭪後の排便状況に変化は認められなかった。一方経腹 街式では，衍前の便秘の有無にかかわらず，術後その 程度が增強した症例は 8 例中 3 例に認めた。 また，術 後愁訴および合併症として，1 例に開腹操作によると 思われる Subileus を認めた。その後 Subileus 状態は 下詴にて改善したが，排便時腹痛，腰痛は続いている。
表 9 吉虂脱の発生メカニスム

(1) ダクラス窝が異常に深く，直腸前面で滑脱へ ルニフを起こす. (Moschowitz, Grahamu)

(2)骨然底中肛門管を形成する諸筋の婜張低下, 弛縟，萎樎がみられる. (Todd, Parks)

(3) 直腸と仙骨の固定不全 (Pemberton, Kummell)

(4) 直腸重積かi主役 (Devadhar, Broden, Ripstein)

\section{考察}

直腸脱の発生メカニズムには定説はなく，現在まで に諸家による発生成因説を要約すると（表 9）のよう になる1).このほか，外肛門括約筋や恥骨直腸筋の筋䉓 図上の活動異常了》組織学的にdenervation t認 め4，骨盤底筋や括約筋の異常が成因の一つとする説 むある2．しかし，直腸脱の原因が明らかでなくてす直 腸脱になった場合の形態学的変化は，ほぼ同じよらな 様相を呈することが知られている。すなわち，肛門括 約筋の弛緩，骨啙底の弱体化，直腸 S 状結腸の過長之 腸間膜の伸展, ダダラス简の過深, 直腸走行の直線化 などであり，直腸手術はこれらを個別的にあるいは複 合的に，修復補正することを目的とし，種々の方法が 提唱されているず.

直腸脱の発生頻度は，隅越ら6)によれば直腸肛門疾 患総数の $0.4 \%$, 小平”によると $2.1 \%$ だり，決っして 多いるのではないので本邦では一施設で多くの症例を 経験しているところはまれである。

男女比は, 欧米では, Beahrs ら ${ }^{8)}$, Moore ${ }^{9)}$,

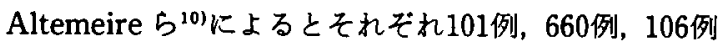
中の男女比は $1: 2.8,1: 3.4,1: 1.5$ と, 女性に多 くみられている。一方, 本邦での荒川の821例の集計11) 
では，男女比は1.7：1と男性に多くなっている.しか し近年女性の発症頻度が徐々に增加する傾向にあ $ろ^{2)}$.

病悩期間は, 荒川111の集計では, 821例では10年以上 が30\%を占め，平均病悩期間は 14.9 年となっている。 欧米では, Theuerkauf ${ }^{22} の 106$ 例の平均病遖期間は男 性13.9年，女性7.1年と報告されている。以上の報告か らみると，直腸脱は本邦欧米ともに男性は比較的若年 で発症し慢性の経過をとるに対して，女性は中年以降 に発病し急速に増悪する傾向を示す”。

病型分類は，辻田 $5^{2}$ 報告では，74例中 I 度：33例 (43.2\%), II 度：38例 (51.4\%), III度：3 例 $(5.4 \%)$ であり，I 度は比較的高龄者に，II 度は若年者に多く みられており，この点は他の報告者でる同様である。

臨床症状では，便通異常を主症状之する頻度は報告 者によって異なる. 荒川 ${ }^{11} に よ る と, 949$ 症状数中71例

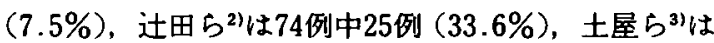
30例中 15例 (50\%)，山内 $5^{13}$ は111例中全例に便秘㑯向 があったと述へ，直腸脱症例のおよそ半数に便通異常 をみるとする報告す少なくない，Ihre ら ${ }^{(5)}$ は残便感あ るいは直腸肛門の閉塞感を直腸脱の特徵的な症状とし てあげ，90例中55例（61\%）に残便感あるいは直腸肛 門の閉塞感の訴えがあり，失禁は37例 $(41 \%)$ ，下浰は 16例（18\%）に認められるなど便通異常を訴える例が 多く，むた手術を要した40例のうち28例（70\%）が便 通異常の改善を目的として手術をらけている。また鳴 海ら"4は32例中15例 (46.9\%)に括約筇不全の徽侯を認 めたと報告している。

直腸脱に対する個々の手術術式と再発率に関して は，現在ほぼ明らかになってきたと言える。それらの 術式の成績を文献により集計した Moore9)の報告によ ると，開腹により直腸つりあげ固定する術式の再発率 は，3〜10\%で最も良好で，他の術式では30～70\%と いら高い再発率を示している.

直腸脱の肛門括約筋の弛縓を改善する「Thiersch 法」は，用いた銀線が離断してしまったり，疼痛の原 因になることがあり，根治性に問題がある，文献によ れば，肛門輪を縮小する「Thiersch 法」たけでは再発 率は高く「Gant-三輪法」を併用することにより再発 率は減るとされている。岩垂ら゙は，「Thiersch 変法」 を施行した14例中 6 例(42.9\%)に再発を，竹村ら ${ }^{16)}$ は， 「Gant-三輪法＋Thiersch 法」を施行した19例中 2 例 (14\%)に再発をみたと報告している。われわれは，繾 縮用材料として銀線の代りにテトロンテープを使った
「Thiersch 变法」と「Gant-三輪法」の併用を施行し良 好な成樍を得た。

一方，直腸固定術は，再発率が低いことが報告され ている. 岩垂ららの報告では, 直腸固定術を施行した37 例中 5 例 $(13.5 \%$ ）に再発をみており，今回われわれ の手術例を検討した結果, 再発率の点からは直腸固定 術が根治性が高いと思われた。

一方，根治性と排便状況改善の両者を满足する点て は，いまたにこれといって有効な術式は無い，報告者 によっても異なるがおよそ半数の症例に便通異常がみ られ，術式を選択するらえで，この点が問題となる。 便通異常の症状としては，便秘が最す多い，便秘が直 腸脱の誘因か結果として出現する症状であるかははっ きりとはしないか，Parks ら4は20例の直腸脱を含む 25例の括約不全を伴 弓症例之 2 例の括約不全を伴わな い直腸脱症例の計 27 例について外括約筋，恥骨直腸筋 および挙肛筋の生検を行い，病理組織学的および組織 化学的検討を加えた結果, denervation とそれに引き 続く, reinnervation のあったことを示寸筋变性の所見 がほとんどの症例にみられ，しかも変化の程度は外括 䄪筋にもっとも強く，举肛筋では比較的軽度であった ことから，長期にわたる便秘に伴ら強いいきみの綝り 返しがこれら筋群扎よび会陰神経，陰部神経の過度の 伸展と損伤を引き起こすに至ったと述べている。鈴 木 ${ }^{1 n}$ の報告では直腸脱之便秘㑯向のある症例 5 例の直 腸肛門管静止压を測定し，直腸肛門反射は全例で正常 であったが，2 例で肛門管内圧が有意に低く，便通異 常と括約不全の関連を示唆している。辻田ら の報告 では，主として直腸剔離，直腸後方固定衍，一部に 「Gant-三輪法」を行った症例では忹とんどの症例で行 後に肛門管内压の上昇をみたるのの，直腸肛門反射は みられてす squeeze pressure（排便時の王）の上界か 不十分な症例も多くみられ，症状の発現はなくとも括 約筋異常は術後かなり長期間残るるのであるとしてい る。また鈴木ら ${ }^{181}$ は，このような便通異常の治療とし て，1）括約作用の強化と，2）直腸詝留能を低下させ て排便反射が起こりやすくすることが必要と考え，释 仙骨的恥骨直腸筋䉽縮によって肛門括約作用の強化を 図り，必要によって直腸腙留能を低下させる目的で前 方切除を加える方法を行い良好な経過を得たとしてい ろ.

術式の選択に関しては，現在まで若年者には根治性 の高い経腹的直腸固定術を，高齢者でリスクの高い場 合には経肛門術式を選択する場合が一般的であり，わ 
れわれも同様の基準で術式を選択した. 天野ら191は, 直 腸肛門内王, 直腸内超音波, 注腸排便造影から直腸脱 の生理学, 動態解剖学を倹討し, 術式を選択施行し, 良好な成績を得たとしている，すなわち，Tuttle 分類 I度では直腸肚門の滑りが主因と考え Gant-三輪法 を，Tuttle 分類II度では盲震化したダクラス窝に腹圧 がかかり腸重積をきたすためと考え，経腹的直腸後方 固定術にダグラス霄を浅くする Sudeck 变法を, 肛門 管内压の低い症例では挙肛筋縫縮術を併用し，いずれ る良好な成績を得たと報告している。

また，手術の合併症にも注意しなければならない。 岩垂ら5゙の報告では，直腸固定術を施行した37例中 1 例にイレゥスを，また37例中 1 例に腹壁へルニフが発 生したと報告している。

\section{結 語}

1962年から1991年までに当科および関連病院が経験 した完全直腸脱18例に施行した手術術式を検討した。 若年者には主として開腹直腸剝離挙上仙骨前固定術 を, 高龄者でリスクの高い者には「Thiersch 法」るし くは「Gant-三輪法」を施行した，18例中 5 例に再発が 認められ，合計26回の手術が行われた。「Thiersch 法」 10回に対して 5 回,「Gant-三輪法」及び「Thiersch 法」 併用 4 回に対して 2 回, 開腹直腸㮃離挙上仙骨前固定 術 8 回に対して 1 回の再発があった。本検討の結果, 以下のことが結論された。

（1）「Thiersch 法」は再発し易く、リスクの高い高 齢者にのみ適応があると思われる。

(2) 開腹直腸剥離挙上仙骨前固定術は再発面からは 効果的な手術であるが，術後排便状況や合併症等に問 題がみられた。

本稿の要旨は第53回日本臨床外科学会総会(德島)にて発 表した。

\section{文献}

1）荒川広太郎：直腸脱。日本大腸肛門病会誌 35 ： 449-453, 1982

2）辻田和䄫，伊藤三則, 大谷忠久他：直腸脱手術症例 の検討. 日本大腸肛門病会誌 $33: 122-127,1980$

3）土屋周二，島津久明，中野春雄他：直腸脱の成因・ 治療方針についての考察。日本大腸肍門病会誌 $24: 149-157,1971$

4) Parks AG, Swash M, Urich H: Sphincter denervation in anorectal incontinence and rectal prolapse. Gut $18: 656-665,1977$
5）岩垂純一, 隅越幸男, 小野力三郎他：直腸脱の㭪式 選択之治療成嘖。外科治療 $59: 7-11,1988$

6）隅越幸男, 高野正博：肛門垁患治療の現況. 日本大 腸肛門病会誌 $23: 36-40,1970$

7）小平 正：肛門疾患の外科的㞠法。日本大腸肛門 病会誌 $15: 1-16,1958$

8) Beahrs $\mathrm{OH}$, Vandertoll DJ, Backer NH, et al : Complete rectal prlapse. An evalation of surgical treatment. Ann Surg $161: 221-224,1965$

9) Moore HD: Comprete prolapse of the rectum in the adult. Ann Surg $169: 368-375,1969$

10) Altemier WA, Culbertson WR, Schowngerdt $C$ et al: Nineteen year's experience with the one stage perineal repair of rectal prolapse. Ann Surg 173 : 993-1006, 1971

11）荒川広太郎：直䭪脱の見㫛. 日本大腸肛門病会誌 $32: 224-229,1979$

12) Theuerkauf FJ Jr, Beahrs oH, Hill JR, et al: Recetal prolapse. Ann Surg 176: 819-832, 1970

13）山内胖, 磯本浩晴, 野北英樹他：直腸脱の治療. 外 科治療 $29: 187-193,1973$

14）鳴海裕行，見滝伸忠，遠藤尚孝他：直腸脱に対する 経肛門的手術の治療効果，日本大腸肛門病会誌 25 : 185-189, 1972

15) Ihre $T$, Seligson $U$ : Intussusception of the rectum-Internal procidentia: Treatment and results in 90 patients. Dis Colon Rectum $18: 391$ -396, 1975

16）竹村 浩, 土屋周二, 小林俊介：経肛門的フプロー チによる手術。日本大腸肛門病会誌 35：476 $-482,1982$

17）鈴木宏志：直腸脱にみられる便通異常の病態生 理。 日本大腸肚門病会誌 $35: 459-462,1982$

18）鈴木宏志，松本好市，三浦 力：直腸に起因与る非 便障害の診断に対する直腸肛門内测定の心用上 ハイオフィードッック上る治瘄。日本大晹肛門 病会誌 $42 ; 997-980,1989$

19）天野信一：直腸肛門内压，直腸内王，直腸内萔音 波，注腸排便造影から々た直腸肛門矣患の病態生 理战上び外科治㞠。日外会誌 90(臨時增刊号)： 374,1989

20) Tuttle JP: A Treatise on the Disease of the Anus. Rectum and Pelvic Colon. Appleton, New York, 1903 


\title{
OPERATIVE RESULTS OF RECTAL PROLAPSE
}

\author{
Tooru FUJIKAWA", Ryuuichi KATAYAMA", Sadao ANAZAWA", Norimasa OKABE ${ }^{21}$, \\ Haruo SAITO ${ }^{31}$ and Kenji SAKURAI ${ }^{11}$ \\ "First Department of Surgery, The Jikei University School of Medicine \\ ${ }^{21}$ Department of Surgery, Kanagawa Prefectural Nurses and Midwives Training School Hospital \\ "Department of Surgery, Atsugi Prefectural Hospital
}

Eighteen patients with complete rectal prolapse treated at the department and related hospitals from 1962 to 1991 were reviewed retrospectively to evaluate operative results in term of the status of recurrence and symptomatic relief.

All 18 patients had rectal prolapse in evaluating, and 11 of them showed constipation, mucous feaces, bleeding or dyschezia. Thirteen patients had sphincteric dysfunction.

As to operative procedures, full mobilization of the rectum and presacral rectopexy by abdominal approach (Rectopexy Procedure) were performed inyounger patients, while in older patients or patients with high risk group Thiersch with or without Gant-Miwa operation was done.

Five out of 18 patients experienced 8 recurrences and a total of 26 operations were conducted.

There were 5 recurrences for 10 operations due to Thiersch method and 2 recurrences for 4 operations due to Gant-Miwa with Thiersch method. Among 8 operations due to rectopexy procedure, only one recurrence was noted.

These results suggested that rectopexy procedure was most excellent in evading recurrence, however, no procedure was able to improve the bowel movement dysfunction. 